\title{
Aktivitas Antibakteri Daun Pepaya (Carica Pepaya) Menggunakan Pelarut Etanol Terhadap Bakteri Escherichia Coli
}

\author{
Tri Puji Lestari Sudarwati ${ }^{1}$ Mercyska Suryandari $^{1}$ \\ ${ }^{1)}$ Program Studi DIII Farmasi Akademi Farmasi Surabaya, Indonesia
}

\begin{abstract}
Abstrak: Isolasi zat aktif dari herba menimbulkan pandangan baru bahwa tiap herba memiliki zat aktif (satu atau lebih). Carica papaya $L$ memiliki zat aktif yang berhasil diisolasi, zat - zat tersebut dapat menggantikan pemakaian herba untuk tujuan pengobatan. Escherichia coli merupakan bakteri yang banyak terdapat di usus besar (colon) manusia dan sebagai flora normal colon, sifat Escherichia coli dapat menyebabkan infeksi primer pada usus besar sehingga menyebabkan penyakit diare. Sampel yang digunakan adalah Daun Pepaya tua berwarna hijau tua yang diperoleh dari UPT Materia Medika Batu. Dicuci bersih kemudian dikeringkan, kemudian dihaluskan dengan cara diblender. Proses ekstraksi menggunakan metode maserasi. Pengujian dilakukan dengan menggunakan 5 konsentrasi dan kontrol negatif. Metode pengujian antibakteri yang digunakan adalah difusi kertas cakram. Diameter zona hambat pada tiap konsentrasi dianalisis menggunakan statistik menggunakan uji ANOVA. Berdasarkan hasil pengujian dengan melakukan replikasi sebanyak 6 kali pada konsentrasi $20 \mu \mathrm{g} / \mathrm{mL}$ dengan rata - rata 7,25 mm, $40 \mu \mathrm{g} / \mathrm{mL}$ dengan rata - rata 7,43 mm, $60 \mu \mathrm{g} / \mathrm{mL}$ dengan rata - rata 7,7 $\mathrm{mm}, 80 \mu \mathrm{g} / \mathrm{mL}$ dengan rata - rata 7,8 dan $100 \mu \mathrm{g} / \mathrm{mL}$ dengan rata - rata 7,9 mm dengan kategori sedang. Dapat dikatakan terdapat pengaruh aktivitas antibakteri pada Daun Pepaya (Carica papaya L) dengan bakteri Escherichia coli maka, semakin tinggi konsentrasi maka daya hambat yang dihasilkan semakin tinggi.
\end{abstract}

\section{Kata kunci : Daun Pepaya, Escheriachia coli, maserasi, antibakteri}

Abstract: Isolation of active substances from herbs raises a new view that each herb has active substances (one or more). Carica papaya $L$ has active substances that are successfully isolated, these substances can replace the use of herbs for medicinal purposes. Escherichia coli is a bacterium that is widely found in the large intestine (human) and as a normal flora of the colon, the nature of Escherichia coli can cause primary infections in the large intestine, causing diarrheal disease. The sample used was dark green papaya leaves obtained from UPT Materia Medika Batu. Washed clean and then dried, then mashed by blending. The extraction process uses maceration method. Tests carried out using 5 concentrations and negative controls. The antibacterial testing method used is paper disk diffusion. Inhibition zone diameters at each concentration were analyzed using statistics using the ANOVA test. Based on the results of testing by replicating 6 times at a concentration of $20 \mu \mathrm{g} / \mathrm{mL}$ with an average of $7.25 \mathrm{~mm}, 40 \mu \mathrm{g} /$ $m L$ with an average of $7.43 \mathrm{~mm}, 60 \mu \mathrm{g} / \mathrm{mL}$ with an average of $7.7 \mathrm{~mm}, 80 \mu \mathrm{g} / \mathrm{mL}$ with an average of 7.8 and $100 \mu \mathrm{g} / \mathrm{mL}$ with an average of $7.9 \mathrm{~mm}$ in the medium category. It can be said that there is an effect of antibacterial activity on Papaya Leaves (Carica papaya L) with Escherichia coli bacteria, the higher the concentration, the higher the inhibitory power produced.

Keywords: Papaya leaf, Escherichia coli, maceration, antibacterial 


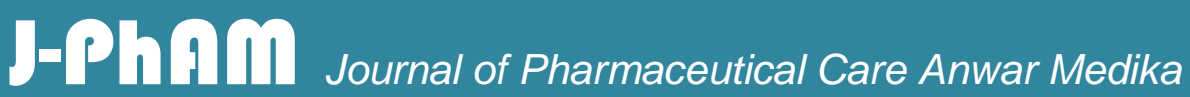

\section{Artikel Penelitian}

\section{PENDAHULUAN}

Infeksi merupakan masalah yang paling banyak dijumpai pada kehidupan sehari hari. Kasus infeksi disebabkan oleh bakteri atau mikroorganisme yang patogen, yang mikroba masuk ke dalam jaringan tubuh dan berkembang biak di dalam jaringan (Waluyo, 2004). Di antara bakteri yang dapat menyebabkan infeksi tersebut adalah Escherichia coli (Jawetz et al.,2005). Escherichia coli adalah bakteri oportunis yang banyak ditemukan di dalam usus besar manusia sebagai flora normal. Sifatnya unik karena dapat menyebabkan infeksi primer pada usus misalnya diare pada anak dan traveler diarrhea, seperti juga kemampuannya menimbulkan infeksi pada jaringan tubuh lain di luar usus. Penyakit penyakit lain yang disebabkan oleh Escherichia coli adalah menginfeksi saluran kemih mulai dari sistitis sampai pielonefritis, pneumonia, meningitis pada bayi dan menginfeksi luka terutama di dalam abdomen (Anonim, 1994).

Dalam pengobatan penyakit infeksi, salah satu masalah serius yang dihadapi kini adalah terjadinya resistensi bakteri terhadap antibiotik yang digunakan (Volk and Wheeler, 1993). Dengan berkembangnya populasi bakteri yang resisten, maka antibiotik yang pernah efektif untuk mengobati penyakit - penyakit tertentu kehilangan nilai kemoterapeutiknya. Sejalan dengan hal tersebut, jelas bahwa ada kebutuhan yang terus - menerus untuk mengembangkan obat - obat baru dan berbeda untuk menggantikan obat - obat yang telah menjadi tidak efektif (Pelczar and Chan, 1988).

Berdasarkan penelitian yang telah dilakukan oleh Oladimeji dkk. (2007), ekstrak etanol daun pepaya memiliki aktivitas antibakteri secara in vitro terhadap bakteri Escherichia coli dengan metode difusi padat cakram berdiameter $6 \mathrm{~mm}$. Hasil penelitian menunjukkan bahwa pada kadar 1,5\% dan $3 \%$ ekstrak etanol daun pepaya mampu menghambat pertumbuhan bakteri pada Escherichia coli dengan zona hambat masing masing 10,0 $\mathrm{mm}$ dan 11,0 $\mathrm{mm}$. Berdasarkan data tersebut maka dilakukan penelitian tentang zona hambat ekstrak etanol daun pepaya (Carica papaya L) terhadap Escherichia coli dengan metode maserasi.

\section{Artikel Penelitian}




\section{J-Ph Am Jounalo of Pharmecoutical Care Amwar Mookka}

Hasil penelitian ini diharapkan dapat memberikan sumbangan dalam menambah wawasan kepada masyarakat tentang obat tradisional dan fitoterapi yang saat ini masih berdasarkan data empiris

\section{METODE PENELITIAN}

\section{Bahan dan Alat}

Alat yang digunakan untuk membuat ekstrak daun pepaya dengan metode maserasi yaitu alat timbangan, maserator, wadah bejana, beaker glass, gelas ukur, erlenmeyer, batang pengaduk, corong, cawan, penangas air, kertas saring, kain flannel, tabung reaksi, rak tabung, wadah toples gelap. Bahan yang digunakan daun pepaya, pelarut etanol.

\section{PROSEDUR PENELITIAN}

\section{Pembuatan ekstrak daun pepaya dengan metode maserasi}

Serbuk daun papaya (Carica papaya L.) kering ditimbang sebanyak 100 g. Selanjutnya diekstraksi menggunakan metode maserasi selama 5 hari dengan menggunakan metanol sebagai pelarutnya sebanyak $1 \mathrm{~L}$ dalam botol yang terhindar dari sinar matahari. Dalam proses maserasi sekali-kali diaduk sampai semua merata. Setelah 5 hari kemudian di evaporator agar mendapatkan ekstrak kental dari daun papaya

\section{Pengujian Aktivitas Daun Pepaya}

Meletakkan 6 kertas cakram dengan diameter $6 \mathrm{~mm}$ pada cawan petri steril, kemudian memipet masing - masing konsentrasi ekstrak daun pepaya sebanyak $30 \mu \mathrm{L}$ dengan

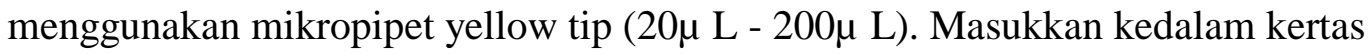
cakram pada cawan petri steril. Mengambil kertas cakram yang sudah ditetesi ekstrak daun pepaya dengan menggunakan pinset steril, dan masukkan kedalam media agar yang sudah diisolasi dengan bakteri Escherichia coli dengan metode spread plate. Diinkubasi dalam inkubator selama 24 jam dengan suhu $37^{\circ} \mathrm{C}$.

Artikel Penelitian 


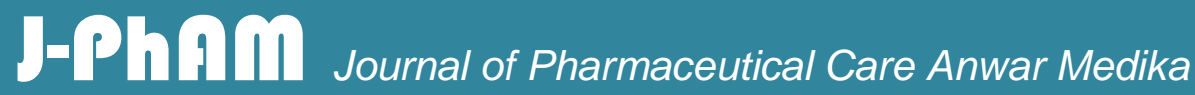

\section{Pengolahan data}

Pengamatan dilakukan setelah inkubasi $24 \mathrm{jam}$ pada suhu $33^{\circ} \mathrm{C}$. Data yang diperoleh :

a. Diameter zona hambat ekstrak daun pepaya yang efektif untuk menghambat pertumbuhan bakteri Escherichia coli disajikan dalam bentuk tabel.

b. Efektifitas ekstrak daun pepaya untuk mengetahui efektivitas zona hambat bakteri Escherichia coli ditampilkan secara deskriptif.

\section{HASIL DAN PEMBAHASAN}

Pengujian pengaruh konsentrasi ekstrak Daun Pepaya (Carica Papaya L) menggunakan pelarut etanol terhadap bakteri Escherichia coli dilakukan dengan menggunakan metode difusi cakram dengan inkubasi selama 24 jam pada suhu $33^{\circ} \mathrm{C}$ dan direplikasi sebanyak 6 kali. Hasil uji aktivitas antibakteri dilihat pada tabel di bawah ini.

Berdasarkan tabel 1 terlihat bahwa ekstrak Daun Pepaya (Carica papaya L) pada konsentrasi tertentu terhadap bakteri Escherichia coli dengan replikasi sebanyak 6 kali menghasilkan diameter rata - rata zona hambat yang sama terhadap bakteri Escherichia coli dengan kategori sedang. Sebagai pembanding menunjukkan bahwa kontrol negatif tidak terbentuk zona bening yang menandakan tidak adanya aktivitas antibakteri yang bekerja untuk menghambat pertumbuhan bakteri Escherichia coli.

Tabel 1. Hasil pengukuran diameter zona hambat bakteri Escherichia coli pada konsentrasi tertentu.

\begin{tabular}{|c|c|c|c|c|c|c|}
\hline \multirow{2}{*}{ Replikasi } & \multirow{2}{*}{$\begin{array}{l}\text { Kontrol } \\
\text { Negatif } \\
\text { - } \\
(-)\end{array}$} & & \multicolumn{3}{|c|}{ Luas Zona Hambat $(\mathrm{mm})$} & \multirow[b]{2}{*}{$100 \mu \mathrm{g} / \mathrm{mL}$} \\
\hline & & $20 \mu$ & $40 \mu$ & $60 \mu$ & $80 \mu$ & \\
\hline 1 & - & 6 & 8 & 7 & 8 & 8,9 \\
\hline 2 & - & 8 & 6 & 8 & 8 & 8,8 \\
\hline 3 & - & 7 & 8 & 7 & 7 & 8,4 \\
\hline 4 & - & 8 & 7 & 7 & 8 & 7,7 \\
\hline 5 & - & 6 & 6 & 7 & 6 & 6,2 \\
\hline 6 & - & 6 & 7 & 6 & 7 & 7,4 \\
\hline Rata- & - & 7 & 7,43 & 7 & 7 & 7,9 \\
\hline Rata & 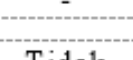 & & & & & \\
\hline Kategori & $\begin{array}{l}\text { Tidak } \\
\text { Alktif }\end{array}$ & Sedang & Sedang & Sedang & Sedang & Sedang \\
\hline
\end{tabular}

Artikel Penelitian 


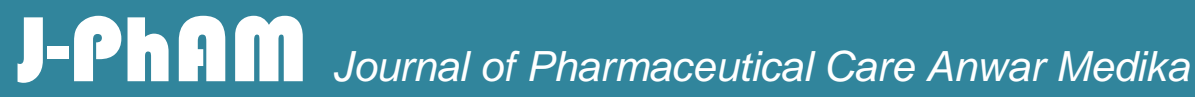

Berdasarkan kurva 1 dapat dilihat dari persamaan regresi nilai $r=0,9804$ maka dapat dikatakan bahwa kurva tersebut linier. Dengan membandingkan zona hambat dari beberapa konsentrasi tertentu yaitu semakin tinggi konsentrasi ekstrak maka zona hambat yang terbentuk semakin tinggi. Menurut Walpole (1995) dapat dilihat dari kenaikan kurva dengan menghitung menggunakan persamaan garis korelasi linier $r=0,9804$. Suatu korelasi $\mathrm{r}=0,90$ dapat diartikan $90 \%$ pada nilai y (zona hambat) terdapat hubungan yang linier dengan nilai x (konsentrasi). Hasil pengujian ini menunjukkan bahwa pengaruh konsentrasi ekstrak Daun Pepaya (Carica papaya L) menggunakan pelarut etanol terhadap zona hambat bakteri Escherichia coli memiliki aktivitas antibakteri dengan kategori sedang pada konsentrasi $20 \mu \mathrm{g} / \mathrm{mL}, 40 \mu \mathrm{g} / \mathrm{mL}, 60 \mu \mathrm{g} / \mathrm{mL}, 80 \mu \mathrm{g} / \mathrm{mL}$ dan $100 \mu \mathrm{g} / \mathrm{mL}$. Kemudian data dianalisis menggunakan statistik SPSS 19 uji ANOVA Oneway.

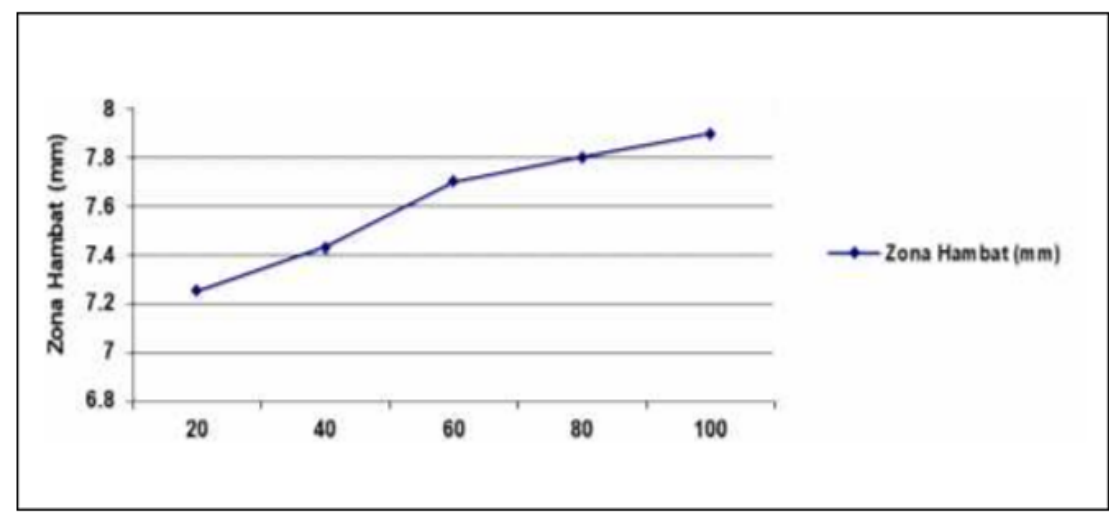

Gambar 1 Kurva diameter zona hambat bakteri Escherichia coli pada konsentrasi tertentu

Pada tabel 2 menunjukkan bahwa nilai sig. 0,000 nilai tersebut $<0,05$ menunjukkan $\mathrm{H} 1$ = diterima, $\mathrm{H} 0$ = ditolak artinya bahwa $\mathrm{H} 1$ terdapat pengaruh konsentrasi terhadap zona hambat. Setelah dilakukan uji ANOVA Oneway dilanjutkan dengan uji Duncan (Tabel 3) untuk menunjukkan perbedaan signifikan pada tiap konsentrasi.

Tabel 2 Uji ANOVA Oneway

\begin{tabular}{|c|c|c|c|c|c|} 
& $\sum \mathrm{ui}^{2}$ & $\mathrm{df}$ & $\overline{\mathrm{U}} 2$ & $\mathrm{~F}$ & Sig. \\
\hline Between & 291.801 & 5 & 58.360 & 67.891 & 0.000 \\
Groups Within & & & & & \\
Groups Total & 25.788 & 30 & .860 & & \\
& 317.590 & 35 & & & \\
\hline
\end{tabular}

Tabel 3 Uji Duncan 


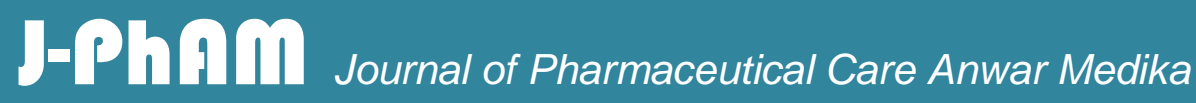

\section{Zona Hambat Bakteri}

Duncan $^{\mathrm{a}}$

\begin{tabular}{|c|c|c|c|}
\hline K & & \multicolumn{2}{|c|}{ Nilai $\alpha=0.05$} \\
0 & 6 & 0.0000 & 2 \\
20 & 6 & & 7.2500 \\
40 & 6 & & 7.4333 \\
60 & 6 & & 7.7000 \\
80 & 6 & & 7.8000 \\
100 & 6 & & 7.9000 \\
Sig. & & 1.000 & 0.288 \\
\hline
\end{tabular}

Subset $(\alpha) 1$ konsentrasi 0 (Kontrol negatif) tidak sama dengan konsentrasi 20 $\mu \mathrm{g} / \mathrm{mL}, 40 \mu \mathrm{g} / \mathrm{mL}, 60 \mu \mathrm{g} / \mathrm{mL}, 80 \mu \mathrm{g} / \mathrm{mL}$ dan $100 \mu \mathrm{g} / \mathrm{mL}$. Subset $(\alpha) 1$ konsentrasi 0 (Kontrol negatif) tidak sama dengan konsentrasi $20 \mu \mathrm{g} / \mathrm{mL}, 40 \mu \mathrm{g} / \mathrm{mL}, 60 \mu \mathrm{g} / \mathrm{mL}, 80$ $\mu \mathrm{g} / \mathrm{mL}$ dan $100 \mu \mathrm{g} / \mathrm{mL}$ pada subset $(\alpha) 2$. Pada subset $(\alpha) 2$ tidak memiliki perbedaan nyata antara konsentrasi $20 \mu \mathrm{g} / \mathrm{mL}, 40 \mu \mathrm{g} / \mathrm{mL}, 60 \mu \mathrm{g} / \mathrm{mL}, 80 \mu \mathrm{g} / \mathrm{mL}$ dan $100 \mu \mathrm{g} / \mathrm{mL}$. Dapat dikatakan adanya beda nyata terkecil dari ke 5 konsentrasi yang dipengaruhi oleh kadar pada masing - masing konsentrasi.

Metode ekstraksi yang digunakan adalah metode maserasi dengan menggunakan pelarut etanol 70\%. Metode ini efektif untuk menjaga kualitas senyawa bioaktif yang tidak tahan panas, selain itu cara pengerjaan dan peralatan yang digunakan relatif sederhana. Etanol merupakan pelarut universal yang baik untuk ekstraksi semua golongan senyawa metabolit sekunder (Kristanti dkk, 2008). Cairan penyari etanol akan menembus dinding sel dan masuk dalam rongga sel yang mengandung zat aktif, zat aktif akan larut dan karena adanya perbedaan konsentrasi antara larutan zat aktif di dalam sel dengan yang di luar sel, maka larutan yang terpekat didesak keluar. Peristiwa tersebut berulang sehingga terjadi keseimbangan konsentrasi antara larutan di luar sel dan di dalam sel (Anonim, 1986).

\section{Artikel Penelitian}




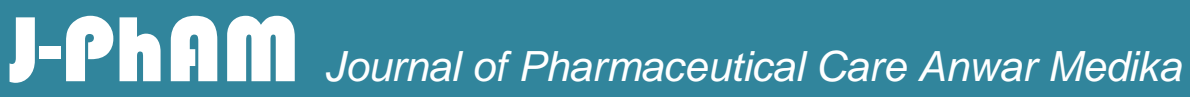

Menurut Baskaran et al (2012) senyawa yang dapat diisolasi dari tanaman yang bersifat sebagai antibakteri yaitu alkaloid. Mekanisme kerja alkaloid yang memiliki kemampuan berinteraksi dengan dinding sel dan DNA (Cowan, 1999). Dari penelitian dilaporkan bahwa alkaloid efektif sebagai antimikroba, karena kemampuan menyusup pada utas ganda DNA dan mempengaruhi enzim topoisomerase dan enzim perbaikan DNA (Cao et al, 2007). Sedangkan pada senyawa fenolik (flavonoid) mekanisme kerja antibakteri bekerja meningkatkan kerja sistem imun karena leukosit sebagai pemakan antigen lebih cepat dihasilkan dan sistem limfoid lebih cepat diaktifkan (Anonim, 2007). Selain itu kompleksasi dari ion besi dengan tanin dapat menjelaskan toksisitas tanin. Mikroorganisme yang tumbuh di bawah kondisi aerobik membutuhkan zat besi untuk berbagai fungsi, termasuk reduksi dari prekursor ribonukleotida DNA. Hal ini disebabkan oleh kapasitas pengikat besi yang kuat oleh tanin. Respon uji daya hambat daun pepaya (Carica papaya) terhadap bakteri Salmonella thypi menujukkan jika pada konsentrasi $20 \mu \mathrm{g} / \mathrm{ml}$ sampai $100 \mu$ $\mathrm{g} / \mathrm{ml}$ masuk kategori zona hambat sedang dalam menghambat pertumbuhan bakteri Salmonella thypi (Sudarwati, 2018)

\section{KESIMPULAN}

Berdasarkan hasil pengujian dengan melakukan replikasi sebanyak 6 kali, dapat dikatakan terdapat pengaruh aktivitas antibakteri pada Daun Pepaya (Carica papaya L) dengan bakteri Escherichia coli, dimana semakin tinggi konsentrasi maka daya hambat yang dihasilkan semakin tinggi. 


\section{J-Ph Am Joumal of Pharmecoutical Care Anwer Mookha}

\section{DAFTAR PUSTAKA}

1. Adachukwu, I. P., Ann, O. O. and Faith, E. U. 2013. Phytochemical analysis of paw paw (Carica papaya) leaves. Int. J. Life Sci. Biothechnol. Pharma Res., 2 (3). http://www.ijlbpr.com/jlbpradmin/upload/ijlbpr_51d451cde89e7 Pdf. Diakses tanggal 1 Februari 2015.

2. Anonim. 1986. Sediaan Galenik. 2-3. Departemen Kesehatan Republik Indonesia. Jakarta. Anonim. 1994. Buku Ajar Mikrobiologi Kedokteran. Fakultas Kedokteran. Universitas Gajah Mada, Yogyakarta.

3. Anonim. 2007. Farmakologi dan Terapi Ed.5. Departemen Farmakologi Terapeutik. Fakultas Kedokteran. Universitas Indonesia.

4. Anonim. 2014. http://kesehatantubuh-tips.blogspot.com/2014/05/.apa-itu-e-coli.html.

5. Anonim. 18 April 2017. http://Manfaatsehat.id/manfaat-daun-pepaya/.

6. Davis, W.W., dan T. R. Stout. 1971. Disc Plate Method of Microbiological Antibiotic Assay. Applied Microbiology. 22: 659 - 665.

7. Depkes RI. 1991. Pedoman Teknis Penyediaan, Pengolahan dan Penyaluran Makanan Rumah Sakit. Depkes RI, Jakarta.

8. Harborne, J. B. 1987. Metode Fitokimia Penuntun Cara Modern Menganalisis Tumbuhan. Ed. 2. Hal. 5. 69-76. Diterjemahkan oleh Kosasih Padmawinata dan Iwang Soedira. ITB Press, Bandung.

9. Hutapea, J. P., dan S. Hidayat. 1991. Inventaris Tanaman Obat Indonesia. Departemen Kesehatan RI, Balitbang Kesehatan.

10. Jawetz, E., J. L. Melnick., E. A. Adelberg., G. F. Brooks., J. S. Butel., dan L. N. Ornston. 1995. Mikrobiologi Kedokteran. Edisi. 20. (Alih bahasa : Nugroho \& R. F. Maulany). Buku Kedokteran EGC, Jakarta.

11. Jawetz, E. J., Melnick, et al. 2005. Mikrobiologi Kedokteran. EGC Jawetz, Melnick \& Adelberg, Jakarta.

12. Kamaruddin, M dan Salim. 2003. Pengaruh Pemberian Air Perasan Daun Pepaya Pada Ayam Respon Patofisilogik Hepar. J Sain Veteriner. 20(1) :5-8.

13. Kristanti, Alfinda Novi., dkk. 2008. "Buku Ajar Fitokimia”. Airlangga University Press, Surabaya. 


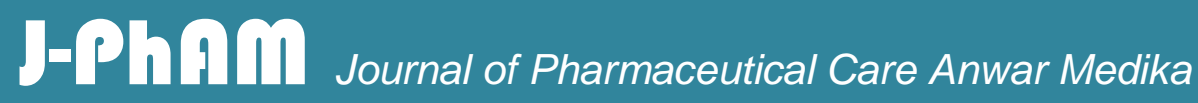

14. Melliawati, R. 2009. E. Coli dalam kehidupan manusia. Bio trends/Vol.4/No.I/Th.2009. Oladimeji, O. H., Nia, R., Ndukwe, K., Attih, M. 2007. In Vitro Biological Activities of Carica Papaya. J of Medicinal Plant. Edisi I. Vol. 3 : 92-99.

15. Pelczar. M.J dan Chan, E. C. S. 1988. Dasar - Dasar Mikrobiologi. Edisi 2. Universitas Indonesia (UI-Press), Jakarta.

16. Pelczar, J. M. 1998. Dasar - Dasar Mikrobiologi Jilid 2. Alih Bahasa : Ratna Ratna Siri Hadiotomo. UI Press, Jakarta.

17. Pratiwi, S. T. 2008. Mikrobiologi Farmasi. Erlangga, Jakarta : 150-171.

18. Sharma, V. C dan O. N. Ogbeide. 1991. Renewable Energy Resource For The Production of Alcohol Fuels 7 (10) : 871-873.

19. Smith, K. P. F. 1988. Genetic Elements in Escherichia coli. London : Macmillan Molecular biology series.

20. Sudarwati, T. P. L. (2018) 'Aktivitas Antibakteri Daun Pepaya (Carica papaya) Menggunakan Pelarut Etanol terhadap Bakteri Salmonella thypi', Journal of Research and Technology.

21. United States Departement of Agriculture. 2001. USDA Nutrient Database for Standart Reference. http://nal.usda.gov/fnic/foodcomp/Search. 15 Setember 2008.

22. Volk, W. A., M. F. Wheeler. 1993. Mikrobiologi Dasar. Erlangga, Jakarta.

23. Walpole, R. E., Raymond H Myers. 1995. "Ilmu Peluang Dan Statistika untuk Insinyur dan Ilmuwan”. Edisi 4. Penerbit ITB, Bandung.

24. Waluyo. 2004. Mikrobiologi Umum : 105-108. Universitas Muhammadiyah Malang Press, Malang.

25. Hembing, W. K. Dalimartha, S. Wirian, A. S. 1994. Tanaman Berkhasiat Obat di Indonesia.

26. Pustaka Kartini, Jakarta. 